\author{
Sebastian Brejnak \\ Uniwersytet Jagielloński \\ sebastianbrejnak@gmail.com
}

\title{
O przymusie i potrzebie powtórzenia w Zapisanym i Spojrzeniu Julii Hartwig
}

\section{On Compulsion and the Need to Repeat in Zapisane and Spojrzenie of Julia Hartwig}

\begin{abstract}
The purpose of the article is to present the late works of Julia Hartwig in the context of the philosophic problems of repetition as approached by Friedrich Nietzsche, Gilles Deleuze, and Jacques Derrida. In the essay an attempt was made to confront the previous readings of the Hartwig's poetry - which placed it usually within the classicizing and modernistic trends - with the alternative lecture, i.e. using the insights of the theorists of postmodernity and contemporary humanities. The ambivalence, reflected in the title, of the poet's attitude towards the very repeatedness in the field of literature has been derived not from the philosophic systems, or contemporary concepts of anthropology and literary studies, but directly from the poetics and the ideational layer of the two last books of Hartwig - Zapisane and Spojrzenie - in which it is the iterability that becomes the idiom both of the human existence, perception, or the mechanisms of memory, andthe writing poetry as such.
\end{abstract}

Keywords: Julia Hartwig, Zapisane, Spojrzenie, contemporary poetry, repetition, iterability, Jacques Derrida, Gilles Deleuze, Czesław Miłosz

Streszczenie: Celem artykułu jest ukazanie późnej twórczości Julii Hartwig w kontekście filozoficznej problematyki powtórzenia w ujęciu między innymi Fryderyka Nietzschego, Gilles'a Deleuze'a oraz Jacques'a Derridy. W szkicu została podjęta próba konfrontacji dotychczasowych odczytań poezji Hartwig, sytuujących ją zwykle w nurtach klasycyzujących i modernistycznych, z lekturą alternatywną - z wykorzystaniem rozpoznań teoretyków ponowoczesności oraz współczesnej humanistyki. Tytułowa ambiwalencja w traktowaniu przez poetkę samej powtórzeniowości w literaturze wyprowadzona została jednak nie z systemów filozoficznych czy współczesnych koncepcji antropologiczno-literaturoznawczych, lecz bezpośrednio z poetyki i warstwy ideowej dwóch ostatnich tomików Hartwig - Zapisanego i Spojrzenia, w których to iterowalność staje się zarówno idiomem ludzkiej egzystencji, percepcji czy mechanizmów pamięci, jak i twórczości poetyckiej jako takiej.

Słowa kluczowe: Julia Hartwig, Zapisane, Spojrzenie, poezja współczesna, powtórzenie, iterowalność, Jacques Derrida, Gilles Deleuze, Czesław Miłosz 
Kiedy napotkam u innego poety obraz lub myśl, które znalazły się już przed tą lekturą w moich własnych wierszach, uczucia moje są zamącone. $Z$ jednej strony cieszy mnie odnalezione nagle braterstwo poetyckie, $\mathrm{z}$ drugiej niepokoi obawa, że jest może w tym obrazie coś pospolitego, skoro się powtórzył. Ale prowadząc tę refleksję dalej. Czy to, co nazwałam „pospolitym”, nie okazuje się czasem cnotą, właśnie dlatego, że łączy się z powszechnością? A ku temu, choć nieraz pokrętnymi drogami, zmiesza przecież sztuka ${ }^{1}$.

Wydaje się, że Julia Hartwig niejednokrotnie mierząca się z tłumaczeniem twórczości modernistów (takich jak: Max Jacob, Guillaume Apollinaire, Blaise Cendrars, Louis Aragon), sama zaś jako poetka często wpisywana w nurt modernistyczny bądź klasycyzujący², odrobiła również lekcję z refleksji postmodernistycznej ${ }^{3}$. Nowoczesny bezwzględny postulat wynalazczości i oryginalności został przez nią ostatecznie rozpoznany jako utopia w ostatnich tomikach - Zapisanym i Spojrzeniu - które w szczególny sposób traktują funkcję powtórzenia w poezji. Przez pojęcie "poezji” rozumie się tu nie tylko konkretne rzemiosło artystyczne, lecz również specyficzny rodzaj kondycji egzystencjalnej polegającej na byciu w języku i doświadczaniu poprzez język pozwala na wyjście poza badanie poetyki powtórzenia w twórczości Hartwig i potraktowanie repetycji jako istotnego zagadnienia filozoficznego, które dotąd w refleksji literaturoznawczej funkcjonowało w odniesieniu do poezji choćby Thomasa Stearnsa Eliota, Czesława Miłosza, Josifa Brodskiego, a także poetów współczesnych, na przykład Eugeniusza Tkaczyszyna-Dyckiego 5 .

W niniejszym artykule podjęta zostanie próba skonfrontowania idiomu powtórzenia reprezentowanego przez Hartwig w późnym okresie twórczości

${ }^{1}$ J. Hartwig, Btyski, Warszawa 2002, s. 54.

2 Zob. między innymi: J. Kwiatkowski, Felieton poetycki, „Twórczośc” 1973, nr 9; Z. Bieńkowski, Azyl: poezja i niepoezja, „Tygodnik Kulturalny” 1988, nr 2; W. Kaliszewski, Klasycyzm i Julia Hartwig, „Więź” 1988, nr 6; A. Nasiłowska, Poezja jako sposób poznania, „Odra” 1996, nr 5; P. Łuszczykiewicz, Być poeta osobnym, „Nowe Książki” 1998, nr 11; B. Pelczar, W kręgu egzystencjalnych pytań tomiku „Zobaczone” Julii Hartwig, „Zeszyty Naukowe Uniwersytetu Rzeszowskiego. Historia Literatury" 2002, z. 1; E. Nikadem-Malinowska, Powiedzieć więcej-rozważania o synestetyzmie w poezji Josifa Brodskiego i Julii Hartwig, „Acta Polono-Ruthenica” 2003, t. 8; E. Dąbrowska, „Mowa petna wahań i zapytañ”- o sztuce poetyckiej Julii Hartwig, ,Język Artystyczny" 2003, t. 12; A. Kałuża, Ziemia niczyja. O problemie podmiotu w poezji Julii Hartwig, „FA-art” 2005, nr 4; M. Telicki, Poetycka antropologia Julii Hartwig, Poznań 2009; A. Kałuża, Wola odróżnienia. O modernistycznej poezji Jarostawa Marka Rymkiewicza, Julii Hartwig, Witolda Wirpszy i Krystyny Mitobędzkiej, Kraków 2008.

3 Warto wspomnieć, że Hartwig była tłumaczką między innymi Allena Ginsberga (Znajomi z tego świata, wspólnie z Arturem Międzyrzeckim, Andrzejem Szubą i Piotrem Sommerem).

${ }^{4}$ Zob. koncepcję autentycznego Bycia w poezji/poprzez poezję autorstwa Martina Heideggera (między innymi: tenże, „...poetycko mieszka cztowiek... ” [w:] tegoż, Odczyty i rozprawy, tłum. J. Mizera, Kraków 2002; tenże, W drodze do jezzka, tłum. J. Mizera, Kraków 2000).

${ }_{5}$ Zob. G. Tomicki, Poetyckie krążenie wokót „Das Ding”. Funkcje powtórzenia w poezji Eugeniusza Tkaczyszyna-Dyckiego, „Pamiętnik Literacki” 2014, nr 4. 
z myślą filozoficzną, między innymi Gilles’a Deleuze'a, problematyzującą powtórzeniowość. Celem tego tekstu będzie jednak nie próba wpisania autorki Czutości w dyskurs ponowoczesności (w obrębie którego dotąd przeważnie nie istniała w krytycznych opracowaniach $\left.{ }^{6}\right)$, lecz danie impulsu do niestandardowej, alternatywnej czy polemicznej ${ }^{7}$ lektury tej poezji.

\section{Typologia powtórzenia}

Repetycja pojmowana tyleż filozoficznie, co strukturalnie - jako paradygmat estetyczny - w wymienionych wyżej zbiorach poetyckich osiągnęła z pewnością najpełniejszą realizację w całym dorobku poetki. Jednocześnie należy stwierdzić, iż powtórzenie jako wyróżnik stylu oraz figura myśli obecne było w niemal całym poetyckim dorobku Hartwig ${ }^{8}$. Największej intensyfikacji uległo jednak w Zapisanym, stając się prymarnym wyznacznikiem poetyki, kompozycji oraz warstwy koncepcyjnej zbioru. W tomiku z 2016 roku natomiast owa tematyzacja powtórzeniowości została przesunięta w stronę idiomu tytułowego „spojrzenia” jako figury przymusu zainteresowania (się) światem powracającym w coraz to nowych formach i konfiguracjach. Jest ono traktowane jako konieczność uważności - percepcyjnej intensywności, będącej udziałem zarówno podmiotu "wpatrującego się” nieustannie w rzeczywistość („rzeczowość), jak i samego świata odwzajemniającego spojrzenie, zarazem patrzącego ${ }^{10}$.

${ }^{6}$ Również w tych najnowszych (często autobiografizujących): zob. A. Legeżyńska, Julia Hartwig. Wdzięczność, Łódź 2017; E. Dutka, Centra, prowincje, zautki. Twórczość Julii Hartwig jako auto/bio/geolgrafia, Kraków 2016.

${ }^{7}$ Niekiedy być może - nadinterpretującej, gdyż osadzającej tę poezję w kontekstach innych od dotychczasowo jej przypisywanych. Chodzi przede wszystkim o prace wpisujące twórczość Hartwig w nurt klasycystyczny czy modernistyczny. Zob. przyp. 2.

${ }^{8}$ Wystarczy przypomnieć tytuły tomów Hartwig, by zauważyć ich wzajemną korespondencyjność. Pozwala ona ułożyć poszczególne zbiory w dyptyki - mając na względzie warstwę treściową lub formalną (gramatyczna) ich tytułów: Pożegnania (1956) - Bez pożegnania (2004), Czuwanie (1978) - Chwila postoju (1980), Obcowanie (1987) - Czutość (1992), Zobaczone (1999) - Spojrzenie (2016), Zobaczone - Zapisane (2013), Nie ma odpowiedzi (2001) Bez pożegnania, Jasne niejasne (2009) - Zapisane, Jasne niejasne - Spojrzenie.

${ }^{9}$ Nietożsamego z podmiotem kartezjańskim, czego nie dostrzega Anna Kałuża, traktując podmiot wierszy Hartwig jako stricte modernistyczny (o proweniencji kartezjańskiej), dualistycznie przeciwstawiony res extensa - uprzedmiotowionej, zdystansowanej rzeczywistości: „(...) Po pierwsze, poetki nie interesują złożone zagadnienia antropologiczne (...). Po drugie, poetyckie przedsięwzięcie utrzymuje ona w ramach myślenia, jakie proponuje kartezjański dualizm (...)”. A. Kałuża, Wola odróżnienia..., dz. cyt., s. 103.

${ }_{10}$ Zob. rozważania Jacuqes'a Lacana na temat relacji między patrzącym i tym, na co się patrzy, której spoiwem jest spojrzenie obdarzone mocą wzajemnego stwarzania się (tenże, Anamorfoza i spojrzenie, tłum. W. Michera [w:] Antropologia kultury wizualnej. Zagadnienia i wybór tekstów, oprac. I. Kurz, P. Kwiatkowska, Ł. Zaremba, Warszawa 2012). 
Owo „spojrzenie” łączy się z figurą „zapisywanego” na polu pamięci, strukturyzowanej przez powtórzenie, dlatego $\mathrm{w}$ jednym $\mathrm{z}$ wierszy pojawia się stwierdzenie: „Nie jest poetą/ ten kto zapisuje/ ale ten co tę chwilę/ na zawsze zapamiętał" 11 . To pamięć zarówno trudna, niekiedy bolesna i napawająca niepokojem, jak i odczuwana jako konieczna i pożądana.

W późnej poezji Hartwig relacja między tym, co rutynowe, odczuwane jako „cnoty codzienności z nawyku praktykowane” ${ }^{12}$, a tym, co wyjątkowe, wydarzające się jednokrotnie, zaciera się w jednostkowej pamięci i (meta)literackiej refleksji. Stąd też wykonywane na co dzień czynności - do których należy także pisanie, ale też przywoływanie zmarłych - sprawiające wrażenie powierzchownych, nieistotnych, „nagich” powtórzeń, nabierają znaczenia dzięki pracy pamiętania oraz poetyckim opracowaniom. W Zapisanym dominujące autotematyczne rozważania nad językiem poezji wspótistnieją nierozłącznie z materią owego języka, czyli doświadczeniem życia. Na nie składać się może natomiast zarówno obserwacja paryskiego pejzażu ${ }^{13}$, corocznie obchodzone święta ${ }^{14}$, jak i rozmyślania nad problemem samotności ${ }^{15}$. W Spojrzeniu proporcje ulegają odwróceniu: akcent zostaje położony na to, co zobaczone, doświadczone, zapamiętane przez podmiot i wyeksplikowane w języku bądź pozostające w sferze milczenia („nie powiem na jak długo/ ani dokąd idę" ${ }^{\prime 6}$ ). W obu tomikach repetycja odgrywa decydującą rolę w konstruowaniu poetyckiego świata naznaczonego i zapisem - czy raczej egzystowaniem w permanentnym stanie zapisywania (bycia pisanym) - jak bytowaniem w cudzym/własnym spojrzeniu.

Można by, w odniesieniu do powyższych wstępnych rozpoznań, wyróżnić kilka umownych obszarów, w obrębie których owo powtórzenie w tomach Zapisane i Spojrzenie ujawnia swoje działanie, wydarzając się jako figura myślenia i poetyckiej kreacji. Byłyby to płaszczyzny:

11 J. Hartwig, ${ }^{* * *}$ (Nie jest poeta) [w:] tejże, Spojrzenie, Kraków 2016, s. 15.

12 Taż, ${ }^{* * *}($ Ile straconych dni) [w:] tejże, Zapisane, Kraków 2013, s. 39.

13 Zob. utwór Paryż (Zapisane).

${ }^{14}$ Zob. dyptyk kończący Zapisane: Wielkanoc-Wigilia.

15 Por. „(...) wypełniająca naszą codzienność materia wrażeń i uczuć staje się pożywką naszej samotności zwróconej ku pisaniu”. J. Hartwig, Dawać do siebie dostęp zachwytowi [w:] Pochwała istnienia. Studia o twórczości Julii Hartwig, red. B. Kulesza-Gulczyńska, E. Winiecka, Poznań 2015, s. 7. „Próbujemy stawić jej [samotności - S.B.] czoła, utrwalając, co kochamy, co nas zadziwia, co sprawia, że przez chwilę wolno nam zapomnieć o klęsce powtórzeń i upokorzeniach podobieństwa”. Taż, Btyski, dz. cyt., s. 90.

Samotność stanowi więc dla Hartwig stan upragniony; nie tyle umożliwia on twórczość poetycką, co jest jej warunkiem koniecznym. Dzięki samotności, twierdzi poetka, nasza rozproszona na co dzień uwaga może się zogniskować na doświadczeniu jako takim. Wytworem tej percepcyjnej fokalizacji jest poezja jako antidotum na „klęski powtórzenia” i „upokorzenia podobieństwa” codzienności. Nie jest ona jednak wyzbyta owej powtórzeniowości czy mimetyczności. Wręcz przeciwnie, inkorporuje je i czyni swą materią. „Klęski” i „upokorzenia” przeobrażają się w niej w świadomość nieodzowności znamion repetycji w ludzkim doświadczeniu (także: w sztuce).

${ }^{16}$ J. Hartwig, Podróżny [w:] tejże, Spojrzenie, dz. cyt, s. 19. 
1. zrekontekstualizowanego repetitio - zabiegu poetyckiego wychodzącego poza sferę retoryki - powtórzenia poddanego filozoficznej i antropologicznej problematyzacji;

2. samej architektoniki tomików pomyślanych jako swoiście zorganizowane konstrukcje, których poszczególne elementy - pojedyncze wiersze - tworzą powtarzające się konfiguracje (na przykład quasi-dyptyki ${ }^{17}$ ), naznaczone nieregularnością, niekiedy celową niekonsekwencją oraz formalną otwartością/niekompletnością, na przykład ${ }^{* * *}$ (To co przeżyliśmy razem) - ${ }^{* * *}($ Jest $w$ tobie wszystko $),{ }^{* * *}(Z$ obcości nie $z$ bliskości rodzi sie wiersz) - ${ }^{* * *}\left(\right.$ Jeżeli cośszto), ${ }^{* * *}($ Stuchajcie jak echo śpiewa $)$ - Sita i stodycz, Wielkanoc - Wigilia, ${ }^{* * *}($ Nie przyzywajcie ich tylko po to $)-{ }^{* * *}($ Graj mi za duzo), ${ }^{* * *}($ Jest wiele ukrytych radości $)$ - ${ }^{* * *}\left(\right.$ Graj mi za dużo), ${ }^{* * *}($ Duch dobry i duch mu przeciwny) - Spojrzenie;

3. intertekstualnego dialogu między utworami, samymi tomikami oraz innymi tekstami kultury, przybierającego postać wędrujących motywów, figur stylistycznych, retorycznych, figur myśli, stylu, konceptów, wreszcie całych fraz czy poetyckich, parafraz, pseudocytatów ${ }^{18}$, na przykład: ***(To co przeżylismy razem), ${ }^{* * *(S t u c h a j c i e ~ j a k o ~ e c h o ~ s ́ p i e w a), ~ G t o-~}$ sy, ${ }^{* * *}($ Radości $)$, Sita i stodycz, ${ }^{* * *}(C z a s y$ nastaty $),{ }^{* * *}(Z$ Appolinaire'a $)$, *** (Wracamy umierac) ${ }^{* * *}$ (Powoli się uczysz), ${ }^{* * *}(\text { To czego nam potrzeba })^{19}$.

Pierwsze typologiczne rozróżnienie wskazuje na ogólny rys problemowy zbiorów Zapisane i Spojrzenie, na który składa się zarówno koncept poietyczny, jak i filozoficzny. Można by go nazwać projektem antropologicznym, wszak dotyczy przede wszystkim doświadczenia człowieka, odczuwającego kulturotwórczą potrzebę nadawania swoim działaniom sensu.

${ }^{17}$ Na podobnej zasadzie, wedle której układają się wiersze w Dwuptacie Szymona Słomczyńskiego (zob. tenże, Dwuptat, Wrocław 2015).

${ }_{18}$ Tym intertekstualnym dialogowaniem wpisanym w samą naturę samego języka zajmowali się między innymi Michaił Bachtin oraz Julia Kristeva. Zob. także: R. Nycz, Poetyka intertekstualna: tradycje i perspektywy [w:] Kulturowa teoria literatury. Gtówne pojęcia i problemy, red. M.P. Markowski, R. Nycz, Kraków 2012.

19 Przykładowo można prześledzić drogę kilku fraz w obu tomikach: „szczątki niezapisanej mowy” (*** [To co przeżyliśmy razem $]$ ) - „to szczątki zapomnianej mowy czasu” (***[Radości $]) ;$, ,miejsca i obrazy czekają na swoje zaistnienie” (***[Stuchajcie jak echo śpiewa]) - „miejsca i obrazy czekały na zaistnienie” (***[Siła i stodycz]) - „zapomniałeś kształtów i barw/ trzeba było stanąć w tej niezamieszkałej pustce/ w miejscu bez miejsca/ w czasie bez czasu” (*** [Minęto]) - „miejsca stracity swoje miejsce” (***[Wszystko pogubit]); „żyjemy między wspominaniem i zapominaniem” (Sita i sto$d y c z)$ - „Żyjemy wspomnieniem/ i zapominaniem” (***[Czasy nastaty]); ,jak przejść do znaków codzienności/ po sprawach ostatecznych” (*** [Wracamy umierać]) - „Jak przejść od znaków codzienności/ do spraw ostatecznych” (Gtosy ze Spojrzenia); „czy umiemy sprostać swojemu losowi” (Sita i stodycz) - „czy zdążymy dorównać swemu przeznaczeniu” (Wyzwanie), „,Każdego ranka/ świat jest nam odmieniony” (***[Jest wiele ukrytych radości]) - „Nie w wybranym nie w oczekiwanym/ miejscu się pokaże ten odmieniony w jednej chwili świat” (Spojrzenie) - „Niech w nieobranym/ nieoczekiwanym/ miejscu się pokaże/ ten odmieniony/w jednej chwili świat” (***[Graj mi za dużo]). 
Figurą tego pragnienia jest w przypadku Hartwig poeta (etymologicznie: ten, który tworzy). Ostatnie tomiki autorki Bez pożegnania są w tym szkicu potraktowane właśnie jako świadectwa metaliterackiej refleksji nad statusem piszącego, mimo braku konwencjonalnie sygnalizowanego autotematyzmu. Nie oznacza to jednak, że podmiot wierszy Hartwig funkcjonuje jako wyabstrahowany, teoretyczny twór podobny poetyckim kreacjom francuskich modernistów, skądinąd cenionych przez poetkę (takich jak: Paul Valéry, Stéphane Mallarmé czy Paul Claudel). Wręcz przeciwnie, opis funkcjonowania powtórzeniowości w sztuce współistnieje u autorki Czutości z zainteresowaniem mechanizmem działania powtórzeń w doświadczeniu egzystencjalnym. Egzemplifikacje tej szczególnej zależności pochodzące z Zapisanego i Spojrzenia ukażą, iż te dwa poziomy - poetyki i egzystencji - są ze sobą u Hartwig trwale zespolone, często: tautologiczne.

\section{Między wspominaniem i zapominaniem}

noc wlewa się jak ciemna woda

żyjemy między wspominaniem i zapominaniem

czy umiemy sprostać swojemu losowi

poznaliśmy śmierć bez umierania

i widywaliśmy światło w ciemności

miejsca i obrazy czekały na zaistnienie

wabiąc wizją doskonałości

zrób co zamierzałeś

bo nigdy nie będziesz gotowy

wezwij dobre duchy

żeby ci sprzyjały ${ }^{20}$

Sita $i$ stodycz to miejsce węzłowe w Zapisanym, w którym kondensuje się problematyka i związana z nią poetyka całego tomiku. To także pryzmat, przez który przechodzą najbardziej czytelne powtórzenia, rozszczepiające się w innych utworach i przyjmujące różne postaci, sytuując się w odmiennych układach, kontekstach. Warto zaznaczyć, iż oprócz całych wyrażeń i fraz powracających w różnych wariantach w tomach Zapisane i Spojrzenie w utworze tym obecne są również najwyrazistsze motywy poezji Hartwig, takie jak: harmonia, ład, pamięć, śmierć, przeznaczenie, sztuka, specyficzna duchologia (z pogranicza chrześcijaństwa i wierzeń ludowych). Wyróżniki poetyki lubelskiej poetki:

${ }^{20}$ J. Hartwig, Sita i stodycz [w:] tejże, Zapisane, dz. cyt., s. 14. 
akwatyczne metaforyzowanie i polifoniczność ${ }^{21}$, efekt obcości, braku intymności wiersza („Z obcości nie z bliskości rodzi się wiersz/ dopuszczasz do siebie obcego/ który chce dojść do głosu"22), także wysuwają się w Sile i stodyczy na plan pierwszy. Nie muszą one przy tym oznaczać heraklitejskiego pantha rei wywołującego poczucie wyalienowania wobec własnego życia, braku partycypacji w przeszłym doświadczeniu („poczucie winy/ nieuczestniczenia”23). Wydaje się, że u Hartwig „woda”, w Zapisanym funkcjonująca właściwie wyłącznie z epitetem „ciemna”, oznacza przede wszystkim płynność granic między tym, co odczuwane jako jasne lub mroczne, swojskie i obce ${ }^{24}$, własne i należące do innego $^{25}$, pamiętane i rzucone w niepamięć, wreszcie: będące domeną życia i śmierci.

(...) Odkrywa po latach wszystko co zagubione

nagle tak żyje tak już żyć nie może

bo siebie już nie odgaduje

a światło co się przed nim odsłania

jest tak gęste że wszystko zataja

I tylko jest ten obraz gdy idzie ku wodzie

i chce zatopić swoją miłość i pamięćć

Taką samą właściwość - płynnej, nomadycznej substancjalności - mają w Zapisanym poszczególne poetyckie wizje. Fraza „miejsca i obrazy czekały na zaistnienie" pojawia się w poprzedzającym Sitę... liryku ${ }^{* * *}$ (Stuchajcie jak echo śpiewa ${ }^{27} \mathrm{w}$ czasie teraźniejszym. Tytułowe echo interpretować można jako figurę owego śladu w czasoprzestrzeni, jaki pozostaje po momentalnym wydarzeniu w zapisie, wrażeniu, sferze afektów. „W bladym świetle widać resztki przedmiotów" [podkr. - S.B.], relacjonuje podmiot, pragnąc poniewczasie przyszpilić w znakach języka to, co wymyka się nazwaniu - dzieje się nagle,

${ }^{21}$ W Zapisanym (jak i innych tomikach Hartwig) głos podmiotu podlega częstym przeobrażeniom, także w obrębie jednego wiersza, występując w różnych osobowych formach (również bezosobowej, na przykład bezokolicznikowej), trybach, czasach itd. Tę swoistą polifoniczność uzyskuje też poetka przez zastosowanie kursywy imitującej cytat.

${ }^{22}$ J. Hartwig, ${ }^{* * *}(Z$ obcości nie z bliskości) [w:] tejże, Zapisane, dz. cyt., s. 7.

${ }^{23}$ Taż, ${ }^{* * *}$ (Poszerzanie terytorium) [w:] tejże, Zapisane, dz. cyt., s. 16.

24 „Nie ma takiego który by nie przeczuwał/ że we wnętrzu jego ciemności/ dokonuje się to co najważniejsze/ a niewypowiedzialne/choć oddalone tylko słabym konturem/ od jasności”. Taż, ${ }^{* * *}(Z$ obcości...) $)$ dz. cyt., s. 7.

${ }_{25}$ Zob. „wiem że są miejsca inne/związane z moim życiem i wierne/ale dla mnie to są już dzieje kogoś/dla kogo nie mam dotarcia”. Taż, Miasto [w:] tejże, Zapisane, dz. cyt., s. 34.

${ }^{26} \mathrm{Taż},{ }^{* * *}$ (Nikomu nie ufać) [w:] tejże, Zapisane, dz. cyt., s. 27.

27 „Słuchajcie jak echo śpiewa/ swoją triumfalną pieśń/ nas już nie ma a ono wciąż jeszcze żyje/ drzewom powierza nasze tajemnice/ a księżyc kiedy na niego patrzę/ tak samo wygląda jak wtedy// W bladym świetle widać resztki przedmiotów/ znaki zatrudnień i życia ludzi którzy za dnia tu bywali/ miejsca i obrazy czekają na swoje zaistnienie/ ja także kiedy odejdę może w ciemności zaświecę". Taż, ${ }^{* * *}$ (Stuchajcie jak echo śpiewa) [w:] tejże, Zapisane, dz. cyt., s. 13. 
teraz. Nie chodzi tu tylko o horacjańskie przekonanie o roli sztuki unieśmiertelniającej ulotną rzeczywistość, lecz przede wszystkim o dyspozycje tkwiące w każdej żywej istocie - do pamiętania, także cielesnego, bez językowej eksplikacji.

Jest nam więc dana tylko resztkowość świata; odłamki bytu tworzą naszą jednostkową pamięć miejsc, obrazów, dźwięków, zmysłowych pobudzeń. Ta pamięć jest jednak zdolna ożywiać - przez przywoływanie, pracę powtórzenia - to, co było („nas już nie ma a ono wciąż jeszcze żyje”). W Sile i stodyczy echo pieśni z poprzedniego liryku już zanika, istnienie dawnych miejsc i obrazów wydaje się bezpowrotnie minione. Jednak sama ich obecność - jako minionych właśnie - nie pozwala na całkowite wyciszenie.

Hartwig przez tę repetycję i znaczące przekształcenie frazy dokonuje metatekstowego zabiegu na własnym wierszu i jego problematyce. Demontuje mechanizm zbrodniczego (przybliżającego ku śmierci) i zarazem zbawiennego (umożliwiającego zapomnienie krzywd) działania czasu ${ }^{28}$ przez banalny, zdawałoby się, chwyt gramatyczny. Zamiana czasu teraźniejszego na przeszły nie zmienia jednak niczego w rzeczywistości poetyckiej. Wydarzenie obecne przechodzi w minione, nie zostaje doszczętnie unicestwione dzięki repetycji dokonującej się jednocześnie: $\mathrm{w}$ doświadczeniu pamiętania i zapisywania. Wszystko odbywa się „między wspominaniem i zapominaniem”, przywoływaniem „dobrych duchów” oraz wypędzaniem demonów przeszłości z „pamięci nieprzekupnej”29. Istnienie tej widmowej - obecnej i nieobecnej jednocześnie - rzeczywistości opiera się więc w sposób nieunikniony na powtórzeniu. Poza nim ginie bez śladu:

(...) jak lekko będziemy teraz
unosić się w powietrzu
rozsiewając upominki
darowane przez życie
(...) Jest wiele tego co nie ginie
nie zapominam
o żadnej dobrej chwili ${ }^{30}$.

Pozostałe egzemplifikacje powtarzalności w Zapisanym dotyczą przede wszystkim „szczątków niezapisanej mowy”31/ „szczątków zapomnianej mowy czasu” 32 , miejsc, które „straciły swoje miejsce”33, bycia „w czasie

${ }^{28}$ Zob. „zbrodnie jakich dokonuje na nas czas”. Taż, ${ }^{* * *}$ (To co się dzieje) [w:] tejże, Zapisane, dz. cyt., s. 41.

${ }^{29}$ J. Hartwig, ${ }^{* * *}($ Jest w tobie wszystko) [w:] tejże, Zapisane, dz. cyt., s. 6.

${ }^{30}$ Taż, ${ }^{* * *}$ (Odjęta byta jedyność) [w:] tejże, Zapisane, dz. cyt., s. 26.

31 Taż, ${ }^{* * *}$ (To co przeżyliśmy razem) [w:] tejże, Zapisane, dz. cyt., s. 5.

${ }^{32}$ Taż, ${ }^{* * *}$ (Radości) [w:] tejże, Zapisane, dz. cyt., s. 12.

${ }^{33} \mathrm{Taż},{ }^{* * *}$ (Wszystko pogubit) [w:] tejże, Zapisane, dz. cyt., s. 36. 
bez czasu” ${ }^{34}$. Wszystkie te wyrażenia i frazy odnoszą się do poczucia „niezamieszkałej pustki”, jaka wypełnia egzystencję pozbawioną konkretnego zakotwiczenia w teraźniejszości. Lęk przed niezapisaniem („niezapisane wspomnienia więdną" ${ }^{35}$ ) i zapomnieniem tego, co się wydarza, czego się doświadcza, to swoisty horror vacui, który przezwyciężyć może jedynie uporczywy i przekorny wobec losu wysiłek unarracyjniania swojego ży$\mathrm{cia}^{36} \mathrm{w}$ poezji. Tą zaś, jak zostało powiedziane na wstępie, nie musi być liryka (jako konkretny rodzaj twórczości literackiej), lecz każdy trud mający na celu tworzenie (gr. poiesis) własnej tożsamości. Przypominanie sobie czegoś, powtarzanie tego, co się zdarzyło, i próba przepracowania owego przypomnianego/powracającego/przywróconego to podstawowy mechanizm, wedle którego przebiega to konstruowanie siebie („widzieć twórczość jako zadanie" ${ }^{37}$ ). Tworzenie jest zatem synonimem odkrywania zapomnianego, rewitalizacji szczątków, resztek, odpadków, z jakich składa się doświadczenie („to szczątki zapomnianej mowy czasu/ którą odkrywasz na nowo”38, „Przez lata zakopywana/ nagle się odsłania/ jej dusza zagubiona" ${ }^{39}$ ). To umiejętność zagospodarowywania pustki własnym doświadczeniem tożsama z odpowiednim rozpoznawaniem swojego losu, właściwym nań patrzeniem ${ }^{40}$ : „Tu widzisz że i pustka/ jest błogosławiona/ choć lękają się jej ptaki”"

Zapisane uznać tedy można, posługując się filozoficzną terminologią ${ }^{42}$, za świadectwo nie-metafizycznego rozumienia powtórzenia ${ }^{43}$. Niewprawny czytelnik mógłby zarzucić Hartwig, że po prostu się powtarza, zapominając o własnych pomysłach. Eksploatuje je wielokrotnie bez dbałości o choćby synonimizowanie własnych metafor, fraz, obrazów, wykorzystując prosty mechanizm kopiuj-wklej (w dodatku nieudolnie, gdyż większość skopiowanych fragmentów nieznacznie różni się między soba) do wytworzenia kolejnych nieoryginalnych poetyckich światów. Byłaby to krytyka przeprowadzona przez klasycznego metafizyka obecności, ku któremu ostrze swej myśli skierował między innymi Gilles Deleuze. On także

${ }^{34}$ Taż, ${ }^{* * *}$ (Minęto) [w:] tejże, Zapisane, dz. cyt., s. 17.

${ }_{35}$ Taż, ***(To co przeżyliśmy razem) [w:] tejże, Zapisane, dz. cyt., s. 5.

${ }^{36}$ Zob. narracyjną teorię tożsamości autorstwa Paula Ricouera (zob. na przykład tenże, Czas opowiadany, tłum. U. Zbrzeźniak, Kraków 2008).

37 J. Hartwig, ${ }^{* * *}$ (Nie wahać się] [w:] tejże, Zapisane, dz. cyt., s. 10.

38 Taż, ${ }^{* * *}$ (Radości) [w:] tejże, Zapisane, dz. cyt., s. 12.

${ }^{39}$ Taż, ${ }^{* * *}$ (Przez lata) [w:] tejże, Zapisane, dz. cyt., s. 15.

40 Do tej konkluzji (w tak radykalnej formie) dotrze Hartwig w Spojrzeniu.

41 J. Hartwig, Spojrzenie, dz. cyt., s. 7.

${ }^{42} \mathrm{Z}$ zastrzeżeniem, iż jej użycie traktowane jest, ze względu na szkicowy charakter tego eseju, z dystansem i w celowym uogólnieniu.

${ }^{43}$ Które w tradycji, tak zwanej metafizyki obecności, miało w zawsze nieudolny sposób próbować naprawić brak, niedobór, ułomność, na którą skazany jest świat empiryczny. 
dokonał rewaloryzacji powtórzenia ${ }^{44}$, wskazując na jego nierozłączne zespolenie z różnicą, akcentującą zmienność, zdolność do różnicowania się, procesualność, nie zaś, faworyzowaną dotąd w zachodniej myśli filozoficznej, toż-samość bytu. Toteż powtórzenie jako cecha języka byłoby, wedle tej koncepcji, swoistym wentylem, dzięki któremu sens (zawsze niepełny) może się w ogóle wydarzać (a nie: trwale uobecnić). Stanowiłby także efektywny sposób poetyckiej artykulacji doświadczenia ${ }^{45}$.

Hartwig, eksponując w Zapisanym zabieg powtórzenia, czyniąc z niego zasadę konstrukcji całego tomu, problematyzuje zarazem kwestię repetycyjności poetyckiego języka (również: języka w ogóle) oraz wyostrza podstawową cechę wszelkiego językowego porozumiewania się. Jest nią zdolność do reprodukowania, żerowania na „resztkach dawnych słów”" ${ }^{46}$, powielania i mediatyzacji sensu, nietraktowanego jednak jako arché - niedosiężny oryginał leżący u podstaw bytu ${ }^{47}$. Dotyka jednocześnie tematu czasu strukturyzowanego w ludzkim odczuwaniu przez wyznaczanie granicy temu, co nie daje się ująć w żadne kategorie. Ta przymusowa organizacja czasowości równałaby się, według poetki, z nieuchronnym naznaczaniem powtórzeniowością zdarzeń niepodważalnie wyjątkowych, tworzących doświadczenie życia. Ten ruch - od zapisu, zatem refleksji meta-literackiej, do egzystencji, stanowiącej domenę meta-fizyki dokonuje się w tomiku Hartwig symultanicznie.

${ }_{44}$ Przed Gilles'em Deleuzem (Różnica i powtórzenie) oraz Jacques’em Derridą (na przykład Marginesy filozofii) „powtórzenie” jako problem filozoficzny pojawiło się w innych kontekstach między innymi u Sørena Kierkekaarda (Powtórzenie), Henriego Bergsona (na przykład Materia i pamięc) czy Friedricha Nietzschego (Radosna wiedza).

45 „Powtórzenie jest mocą języka; nie tłumacząc się bynajmniej w sposób negatywny, przez brak, jaki miałby charakteryzować pojęcia nominalne, implikuje ono Ideę zawsze nadmiernej poezji”. G. Deleuze, Różnica i powtórzenie, tłum. B. Banasiak, K. Matuszewski, Warszawa 1997, s. 396.

Por. z refleksją Jacques’a Derridy nad „powtarzalnością” w języku. Francuski myśliciel wskazywał na „iterowalność jako przynależną pismu właściwość ciągłego uogólniania i udostępniania, ale też odtwarzania we wciąż innym wymiarze tego, co idiosynkratyczne. Ta cecha umożliwiałaby uprzystępnienie w zapisie, zrozumiałym dzięki kodowi opierającemu się na regułach znanych innym użytkownikom danego języka, radykalnie niezrozumiałego i nietranzytywnego doświadczenia Innego. Poezja zatem i jej idiomy (jak imiona - jednocześnie skrajnie jednostkowe i współdzielone z innymi) właśnie przez powtórzenie staje się komunikatywna. Zob. J. Derrida, Sygnatura, zdarzenie, kontekst, tłum. J. Margański [w:] tegoż, Marginesy filozofii, tłum. A. Dziadek, J. Margański, P. Pieniążek, Warszawa 2002; J. Derrida, Pozycje, tłum. A. Dziadek, Katowice 2007. Zob. także: M. Zaleski, Nuda powtórzeń? [w:] Nuda w kulturze, red. P. Czapliński, P. Śliwiński, Poznań 1999, s. 58; M.P. Markowski, Efekt inskrypcji. Jacques Derrida i literatura, Bydgoszcz 1997, s. 215.

$46 \mathrm{~J}$. Hartwig, ${ }^{* * *}($ Jeżeli cośszto] [w:] tejże, Zapisane, dz. cyt., s. 8.

47 „Tak oto [według Derridy - S.B.] (...) zasada powtórzenia powinna zostać uznana za zasadę prymarną i odgrywającą rolę oryginału; zasadę pierwszą - gdy chodzi o nasz sposób doświadczania świata”. M. Zaleski, Nuda powtórzeń, dz. cyt., s. 55. 


\section{„Poeta żyje powtórzeniem”48}

Warto w tym miejscu wspomnieć o Miłoszowskiej koncepcji poety, który „żyje powtórzeniem”. Miłosz, ceniony przez Hartwig i często obecny w jej twórczości ${ }^{49}$, uznawany jest za obrońcę mimesis, który radykalnie przeciwstawia się konstruktywizmowi, będącemu domeną poststruktualizmu ${ }^{50}$. Powtórzeniowość przezeń przywoływana w wierszu z 1953 roku nie ma jednak, podobnie jak u Hartwig, nic wspólnego z pantekstualizmem. Odnosi się natomiast do procesu usensowniania doświadczenia, jaki dokonuje się w poetyckim akcie twórczym zawsze post factum. Rozpamiętywanie i proces artystycznej obróbki tego, co zobaczone i przeżyte, to, zdaniem obojga poetów, warunek podstawowy poezji w ogóle.

Model ten pokrywa się w dużej mierze z Eliotowskim paradygmatem uniwersalizacji w literaturze tego, co subiektywne. Bez owego uogólnienia w ogóle niemożliwe byłoby istnienie twórczości artystycznej jako takiej ${ }^{51}$. Akcent zostaje tu przesunięty wyraźnie (w porównaniu choćby z rozważaniami poststrukturalistów) w stronę esse, które nie oznacza tu esencjalnego bytu, lecz poetyckie be-or-not-to-be, grę obecności i nieobecności, reprezentacji i niepochwytności rzeczy („prawdziwe życie jest nieobecne” ${ }^{52}$ ). To napięcie fundujące elementarne doświadczenie poety jako poety (zarazem poety jako człowieka) dotyczy przede wszystkim relacji między autentycznym przeżyciem, jednorazową epifanią, niepowtarzalną obserwacją a repetycją owego doświadczenia w poezji - nieuniknioną, zawsze jakoś przekształcającą i zawsze opóźnioną wobec teraźniejszości.

${ }^{48}$ C. Miłosz, ${ }^{* * *}(W$ metrze paryskim kartki rozcinatem) [w:] tegoż, Wiersze, t. 2, Kraków 1993, s. 27.

49 Żeby wspomnieć tylko o wierszu poświęconym mu w Spojrzeniu (Wyzwanie).

50 Zob. M. Zaleski, Mitosz, poeta powtórzenia, „Teksty Drugie” 2001, nr 3-4, s. 28. Zob. tenże, Zamiast. O twórczości Czestawa Mitosza, Kraków 2005.

${ }^{51}$ Być może Hartwig można by nazywać „klasyczną” (jeśliby się już posługiwać tym nieco niefortunnym pojęciem) właśnie w ujęciu Eliotowskim, w którym bycie klasykiem nie oznacza poznawczej harmonii, pewności, poczucia egzystencjalnego spełnienia przez świadomość mocnego osadzenia w kulturowym dziedzictwie, lecz stan wewnętrznej dojrzałości pozwalający na dystansowanie się wobec własnej teraźniejszości, krytycyzm wobec przeszłości (zatem nie bierną afirmację dawnych - klasycznych - wzorców) oraz „brak świadomych obaw co do przyszłości" (T.S. Eliot, Kto to jest klasyk, tłum. H. Pręczkowska [w:] tegoż, Kto to jest klasyk i inne eseje, tłum. M. Heydel i in., Kraków 1998, s. 70). Dojrzałość ta wynikałaby nie tylko z wiedzy, erudycji, rzemiosła twórcy, ale także jego zdolności do bycia nowatorskim przez korzystanie z dorobku „poprzedników”. Kolejnym warunkiem byłoby wyzbycie się ułudy absolutnej oryginalności. Można by, upraszczając, stwierdzić, że „klasyczność” Hartwig polega przede wszystkim na umiejętności wykorzystania twórczego potencjału powtórzenia (tego, co już było: w kulturze, języku, doświadczeniu etc.). Ta dyspozycja opiera się przede wszystkim na pewnego rodzaju uniwersalizującej metaświadomości, której podstawę stanowi nie tyle akceptacja faktu powtarzalności w sztuce, ile uczynienie z niego głównego motoru tej sztuki.

${ }^{52}$ J. Hartwig, ${ }^{* * *}\left(W_{s z y s t k o ~ b y t o)}\right.$ [w:] tejże, Zapisane, dz. cyt., s. 23. 
Ten nieusuwalny anachronizm, na którym opiera się twórczość poetycka, zarazem każda ludzka działalność, nie jest jednak źródłem egzystencjalnego pesymizmu. Wręcz przeciwnie, stanowi źródło afirmacji poezji „ocalającej” rzeczywistość właśnie przez powtórzenie, dzięki któremu to, co minione, może być stale uobecniane, aktualizowane. „To co się dzieje już wcześniej się działo/ w myślach i w ciemnych znakach nocnych"53, wydarza się za każdym razem na nowo w poezji. Formuła Koheleta (cytowanego przez Hartwig $\mathrm{w}^{* * *}($ Zważono cię) - Nihil novi sub sole - nie musi zatem oznaczać poczucia wyczerpania i wtórności, na jakie skazany jest każdy poeta i każdy użytkownik języka, lecz może być gestem twórczego przetwórstwa.

\section{Jasność widoku mimo wszystko}

To czego nam potrzeba

to jasność widoku

życie ile się uda oczyszczone z mułu

i to pragnienie jakże naturalne

ażeby zajrzeć głębiej niźli rzeczy płyną

znaleźć to co pozwoli

trwać we własnym świecie $(\ldots)^{54}$.

(...) Wierzę że obdarowano mnie jak trzeba

kiedy indziej że dano mi więcej niż zasłużyłam

stąd duma i niepokój

ile straciłeś i co zaniedbałeś

Nigdy nie opuszczać gtębi

i trwać $w$ dialogu z mrocznymi sitami $i^{55}$.

Reprezentację Miłoszowej strategii rozumienia powtórzenia odnaleźć można niewątpliwie w Spojrzeniu, w którym Hartwig przenosi problem powtórzenia w inny niż w Zapisanym rejestr poetyckiej dykcji. Składnia i metaforyka poetki, w porównaniu z tomem z 2013 roku, ulega znaczącemu uproszczeniu, niekiedy balansując na granicy anakolutu (jak w Podróżnym). Upodabnia się niejednokrotnie do języka potocznego i syntaksy, którą uznać można za właściwą potocznej komunikacji bądź pracy myślenia czy pamięci ${ }^{56}$. To pęknięcie, akcentowanie własnej słabości, które można

${ }^{53}$ Taż, ${ }^{* * *}$ (To co się dzieje), [w:] tejże, Zapisane, dz. cyt., s. 41.

${ }^{4}$ Taż, ${ }^{* * *}$ (To czego nam potrzeba) [w:] tejże, Spojrzenie, dz. cyt., s. 33.

55 Taż, ${ }^{* * *}$ (Lato zaptonęto i zgasto) [w:] tejże, Spojrzenie, dz. cyt., s. 38.

56 Co przez dwudziestowiecznych awangardowych twórców było wyzyskiwane w tak zwanym strumieniu świadomości czy pisaniu automatycznym. 
zaobserwować w języku Spojrzenia, koresponduje z doniosłymi filozoficznie tematami. Wśród nich pojawia się, niewybrzmiewający tak mocno w Zapisanym, problem sprzeczności, współistnienia przeciwieństw, leżących u podstaw świata (zwłaszcza w utworze ${ }^{* * *}[$ Duch dobry $i$ duch mu przeciwny]). To rozdarcie niejednokrotnie wypełnia doświadczenie człowieka pragnącego harmonii i ,jasnych widoków” poczuciem egzystencjalnego dysonansu.

Najistotniejszym przesunięciem, z perspektywy omawianej w tym szkicu poetyki powtórzenia, jest jednak konceptualizacja ludzkiej percepcji wzrokowej jako zdolności umożliwiającej człowiekowi wieczny powrót do zobaczonych kiedyś widoków, doznanych przeżyć, rozmów, relacji. Percepcyjność stanowiłaby też potencjał zaznawania nowych, dotąd nieodkrytych jakości. Domniemane okulocentryczne ${ }^{57}$ zorientowanie tomiku ${ }^{58}$ nie ma jednak na celu dowartościowania zmysłu wzroku w procesie poznawczym, lecz wskazanie mechanizmu, na jakim opiera się „spojrzenie”. Jest ono rozumiane jako figura elementarnej podmiotowej dyspozycji odpowiedzialnej za doświadczanie rzeczywistości w zachwycie i zdziwieniu ${ }^{59}$. Nie funkcjonuje zatem jako narzędzie władzy nad obserwowanym światem, jest przeciwieństwem Foucaultowskiego „spojrzenia wiedzącego podmiotu" ${ }^{60}$. Spojrzenie u Hartwig przede wszystkim zostało bowiem obdarzone mocą nieustannego „odmieniania świata" ***(Jest wiele ukrytych radości), Spojrzenie, ${ }^{* * *}$ (Graj mi za dużo), sprawiania, iż dla doświadczającego go człowieka jest on zawsze nowy.

Nie w wybranym nie w oczekiwanym

miejscu się pokaże

ten odmieniony w jednej chwili świat ${ }^{61}$.

Owa „nowość” to przede wszystkim synonim zmiany, metamorfozy, jaka dokonuje się w rzeczywistości dzięki patrzącemu nań podmiotowi („spojrzenie które ukazuje świat/ w obrazie godnym litości/ to znów w kształcie budzącym pożądanie" $\left.{ }^{62}\right)$. Odnawianie świata ${ }^{63}$ wiąże się zatem nie z pragnie-

57 Nie chodzi tu o, stworzoną przez Martina Jaya, koncepcję „okulocentryzmu”, czyli uprzywilejowania percepcji wzrokowej w zachodnioeuropejskiej kulturze, prowadzącego do europocentryzmu, lecz szczególną uwagę, jaką samemu problemowi „patrzenia” poświęca poetka. Okulocentryzm traktowany jest więc $\mathrm{w}$ tym wypadku w dosłownym znaczeniu.

$58 \mathrm{~W}$ którym to, jak się zdaje, zainteresowanie poetki zagadnieniami wizualności, przejawiające się od początku jej twórczości, doprowadzone zostało ad extremum.

59 Przypominającym miejscami „zdumienie” Wisławy Szymborskiej.

${ }^{60} \mathrm{M}$. Bal, Wizualny esencjalizm i przedmiot kultury wizualnej, tłum. M. Bryl, „Artium Quaesiones" 2006, t. 17, s. 306.

${ }^{61}$ J. Hartwig, Spojrzenie [w:] tejże, Spojrzenie, dz. cyt., s. 7.

${ }^{62}$ Taż, ${ }^{* * *}$ (Duch dobry i duch mu przeciwny) [w:] tejże, Spojrzenie, dz. cyt., s. 6.

63 „Postrzegać to za każdym razem inaczej znaczy odnawiać to, zwielokrotniać dla samej tej rzeczy”. F. Pessoa, Księga niepokoju spisana przez Bernarda Soaresa, pomocnika ksiegowego w Lizbonie, tłum. M. Lipszyc, Kraków 2013, s. 107. 
niem unikatowości i oryginalności doznań, lecz z umiejętnością widzenia dysautomatyzującego (gdyby posłużyć się określeniem Wiktora Szkłowskiego). Taka ożywcza percepcja umożliwiałaby twórcze wyzyskanie potencjału powtarzalności stanowiącej inherentną cechę zarówno doświadczenia życia, jak i twórczości artystycznej.

Spojrzenie tak rozumiane cechuje się także fragmentarycznością, niepełnością i uporczywą iteracją ujmowanych obrazów rzeczywistości. Pozbawione jest opresywnego charakteru, naddatku panoptycznej wiedzy o tym, co widziane, oraz poczucia dominacji nad innymi zmysłami i kreowaną przez siebie reprezentacją świata. Nie da się również podporządkować logosowi, uprzedmiotowić do roli epistemologicznego narzędzia umysłu marginalizującego wszystko to, co cielesne, wrażeniowe, przygodne. Nie należy też do władz samego podmiotu ${ }^{64}$, sytuuje się bowiem między tym, kto patrzy, a tym, co jest obiektem ${ }^{65}$ spojrzenia („,to nie ja ale przeze mnie to patrzy" ${ }^{66}$ ). To figura samej czynności patrzenia, procesu, który się wydarza i jest powtarzany bez logicznej ciągłości czy reguły, zaskakując tym, co/jak/kiedy i w jakim kształcie ukazuje. Interpretacja obrazów - niestatycznych, poruszanych przez jednostkową wyobraźnię - za jakich wytwarzanie odpowiada owo spojrzenie, zawsze będzie niekompletna, dla samego interpretującego zagadkowa, nieharmoniczna ${ }^{67}$. „Dumie” istnienia towarzyszy „niepokój”,

64 „Patrzenie bowiem to antidotum na przesadne zainteresowanie sobą”. R. Przybylski, $A k$ ceptacja sprzeczności, [w:] Pochwata istnienia..., dz. cyt., s. 37-38.

${ }^{65}$ Jean-Paul Sartre pisał o spojrzeniu, które zawsze zaskakuje, reorganizując każdorazowo pozycję patrzącego podmiotu (który może być też widziany przez Innego), stawiając go zawsze w relacji: byciu-z-innym (J.-P. Sartre, Spojrzenie [w:] tegoż, Byt i nicość. Zarys ontologii fenomenologicznej, thum. J. Kiełbasa, P. Mróz, R. Abramciów, R. Ryziński, Kraków 2007). Jacques Lacan zwracał natomiast uwagę na „widoczność”, nieprzezroczystość samego spojrzenia w procesie widzenia (zob. przyp. 4). Całkowicie przedefiniował również (inspirując się między innymi Maurice'em Merleau-Pontym) kartezjański - geometralny - model patrzenia, rewaloryzując istnienie Innego (którym może być także przedmiot) przez zrównanie jego pozycji z podmiotem patrzącym/obserwatorem. „To, czym jest światło, patrzy na mnie, i dzięki temu światłu coś się maluje w głębi mojego oka - co nie jest po prostu konstruowaną relacją, przedmiotem, nad którym zatrzymuje się filozof - lecz odciskiem, strużką powierzchni, która nie została tam z góry już umieszczona, dla mnie, w swoim oddaleniu". J. Lacan, dz. cyt., s. 379.

${ }^{66}$ J. Hartwig, Noc [w:] tejże, Gorzkie żale, Kraków 2011, s. 50.

${ }^{67}$ Czemu przeczyłby pozornie, stale obecny w poezji Hartwig, motyw nieustannego poszukiwania przez podmiot harmonii. Owo pragnienie, które traktować należałoby raczej jako figurę nieustannie podejmowanej próby odczarowywania rzeczywistości (przez ciągłe powtarzanie, powracanie do tego samego tematu) aniżeli realną wiarę w możliwość harmonicznego świata, stanowi jeden z powodów, dla których poezję autorki Spojrzenia uważa się za wpisującą się w nurt współczesnego klasycyzmu. „[czy - S.B.] projekt poezjowania Julii Hartwig: wychylony ku afirmacji bytu, skoncentrowany na wsłuchiwaniu się w nieharmonijne często rytmy świata, łączący niepokój z ekstatycznym zachwytem, projekt skoncentrowany na patrzeniu i empatycznym współodczuwaniu, zabezpieczający trwanie na przekór wiedzy o nieuchronnej przemijalności ludzi i chwil, chroniący język poetycki przed zbytnią subiektywizacją, ale nie przed zaangażowaniem, nazwać możemy postawą klasyczną? Jestem o tym przekonana”. A. Stankowska, 
będący oznaką samokrytycyzmu, pragnienia autentyczności, które nie pozwala na wygładzanie konturów rzeczywistości, wprowadzanie do niej idyllicznego fałszywego uspokojenia ${ }^{68}$.

(...) Życie przez poezję mówi swoje rzeczy, ale to ja muszę być świadoma różnic pomiędzy uczuciami i myślami a ich zapisem. Ja muszę czuwać nad miejscem, w którym się spotykają. To ja również przed wierszami stawiam jakieś zadania ${ }^{69}$.

Jedyne, co pozostaje podglądaczowi postawionemu w obliczu kalejdoskopowo przewijających się przed jego oczami (po)widoków, tworzących coraz to nowe kombinacje w powtarzającym się rytmie jednostkowych spojrzeń (zawsze w liczbie mnogiej), przeoczeń, utrwalonych kulturowo obrazów i miejsc pozbawionych przedstawienia ${ }^{70}$, to zapisywanie (,Patrzeć uważnie. Zapamiętywać./ Zacząć nieśmiertelność już tu, na ziemi”1). Ten zapis nie może jednak zastygnąć w nieruchomej formie, lecz musi istnieć w ciągłym stawaniu się, w wiecznym aspekcie niedokonanym („Nasz czas przeszły/ to nadal czas niedokonany"72). Zapis niepochwytnego czasu jest niemożliwy. Zapisywanie czasu, a raczej pisanie czasu - towarzyszenie mu dzięki pracy refleksyjnego pamiętania i umiejętnego, uczestniczącego patrzenia okazuje się natomiast konieczne w efektywnym doświadczaniu, czyli wytwarzaniu, rzeczywistości.

Jak zapisać ten czas

jest choroba i ból

i jest ulga w bólu

byt wciąż niespokojny

bezmiar nieistnienia

Czutość wobec istnienia. Wokót postawy klasycznej Julii Hartwig [w:] Pochwata istnienia..., dz. cyt. s. 51 . Zob. przyp. 45.

${ }_{68}$ Por. z koncepcją Heideggerowskiej trwogi oraz ek-stasis (wyjścia poza stan egzystencjalnego spoczynku, spokoju) jako fundamentów tak zwanego życia autentycznego. M. Heidegger, Bycie i czas, tłum. B. Baran, Warszawa 1994, s. 191-194, 252.

${ }^{69} \mathrm{~J}$. Hartwig, Największe szczęście, największy ból. Jarostawa Mikotajewskiego rozmowy z Juliq Hartwig, Kraków 2014, s. 70.

70 „Są to obrazy [osobiste miejsca pamięci (Pierre'a Nora) - S.B.] przestrzeni realnych modelowane przez zastosowanie dwojakiego rodzaju filtrów: indywidualnej percepcji wzrokowej, dla której charakterystyczne jest notowanie barwy i materialnego szczegółu, oraz - to drugi filtr - kulturowej percepcji widzianego, "wdrukowanej« w świadomość podmiotu przez oglądane wcześniej obrazy malarskie”. A. Legeżyńska, Gdyby Czestaw Mitosz byt kobietą... [w:] Pochwata istnienia..., dz. cyt., s. 25.

${ }^{71}$ J. Hartwig, Btyski, dz. cyt., s. 79.

${ }^{72}$ Taż, ${ }^{* * *}\left(W_{s z y s t k o ~ b y t o)}\right.$, dz. cyt., s. 23. 
pragnienie pociechy bez trwóg

nie mów już o tym więcej

cisza daje $\mathrm{znak}^{73}$.

\section{„Kto mi to zabroni” ${ }^{74}$}

Hartwig w swoich ostatnich tomikach nie tylko konceptualizuje więc powtarzalność, jaka znamionuje ludzką egzystencję we wszelkich jej przejawach: od „codziennej krzątaniny umysłu”75 i doświadczenia w ogóle (bez rozróżniania na to, co somatyczne i duchowe, zmysłowe i inteligibilne etc.) po pracę patrzenia (nie zawsze własnym wzrokiem: „O spojrzeć jego oczami” ${ }^{\text {) }}$ ), ale także wpisuje ją w swój poetycki idiom. Powtarzanie to proces zapamiętywania i zapisywania, również zapominania i przemilczania własnych doświadczeń, ponieważ pismo, jak wiadomo od czasów Platona, to zarówno lekarstwo, jak i trucizna dla pamięci („Tyle napisał a jego życie wciąż nie zapisane"77). Repetycja tak potraktowana przestaje być balastem, sygnałem zagubienia się w języku, wyrazem lęku przed literacką niewydolnością. Staje się natomiast dumnie odkrytym i powtarzanym bez kompleksów znakiem ograniczeń poezji ${ }^{78}$. Ta samowiedza, nietożsama z niebezpiecznym dla każdego twórcy poczuciem duchowej sytości, gdyż oznaczająca de facto przyznanie się do niepewności, okazuje się prawdziwą wolnością („kto mi to zabroni”, „,o komu do tego"79), wyzwoleniem z paraliżującego strachu przed koniecznością egzystowania w języku i poprzez język. Jest więc świadomością twórczego potencjału graniczności poetyckiego wysłowienia oraz sygnaturą przekornego wymykania się logice zero-jedynkowego wartościowania fałszywego rozróżnienia na oryginał i kopię.

Owo odkrycie nie zbliża jednak Hartwig ani o krok do ironicznego sceptycyzmu, przynajmniej jeśli chodzi o rolę poezji w nieustannym odnawianiu „straconego czasu”. Jej filozofia powtórzenia jest dosłowna - to umiłowanie mądrości, jaką daje wiedza o nieuniknionej powtórzeniowości własnego

73 Taż, ${ }^{* * *}$ (Jak zapisać ten czas), tamże, s. 21.

${ }^{74}$ Taż, Podróżny, dz. cyt., s. 19.

75 Taż, Btyski, dz. cyt., s. 5.

76 Taż, Spojrzeć [w:] tejże, Wiersze wybrane, Kraków 2010, s. 268.

77 Taż, CV [w:] tejże, Gorzkie żale, Kraków 2011, s. 54.

${ }^{78}$ Zwięzłość, radykalna intensyfikacja treści w jak najmniejszej liczbie znaków, brak „waty słownej", poetycznej ornamentyki to nie tylko postulaty klasycystycznej poetyki, ale także jedno z głównych założeń projektu poetyki Stanisława Barańczaka (podzielanego też przez wielu przedstawicieli tak zwanej poezji lingwistycznej). Zob. S. Barańczak, Tablica z Macondo [w:] tegoż, Tablica z Macondo: osiemnaście prób wyttumaczenia, po co i dlaczego się pisze, Londyn 1990.

79 J. Hartwig, Podróżny, dz. cyt., s. 19. 
pisarstwa. W tym wypadku aprobata nie oznacza jednak spokojnej zgody na zastany, harmoniczny, niezmienny porządek rzeczywistości. Ta trudna afirmacja powtórzenia („Ośmiel się wreszcie powiedziećl jak trudna jest radość”" ${ }^{80}$, eliminując modernistyczny strach przed byciem nieoryginalnym („,bo i na słowa jest moda" ${ }^{81}$ ), staje się potrzebą powtórzenia, ufundowaną na świadomości jego sensotwórczego potencjału. To pozornie paradoksalne pragnienie, pobudzające do ciagłego działania poprzez pracę wzroku (Spojrzenie) i pióra ( $\mathrm{Za}$ pisane), krystalizuje się we wciąż zaskakującym, nigdy nieodczuwanym jako takie samo, doznawaniu świata i jego poetyckich inskrypcjach, zawsze anachronicznych (powtórzonych) wobec doświadczenia.
Dlaczego je chwalę
i skwapliwie zbieram argumenty
na jego korzyść
choć wiem że mnie oszuka
że porzuci jak wyssaną do szpiku kość
jak wypalony papieros jak zgraną płytę
z której coraz trudniej odsłuchać słowa
Czy robię to z przymusu czy dla wygody
i uspokojenia
(...) Chwalę je wbrew wszystkiemu
wbrew jego zdradzieckiej naturze $(\ldots)^{82}$.

\section{Bibliografia}

Bal M., Wizualny esencjalizm i przedmiot kultury wizualnej, tłum. M. Bryl, „Artium Quaesiones" 2006, nr 17.

Barańczak S., Tablica z Macondo [w:] tegoż, Tablica z Macondo: osiemnaście prób wyttumaczenia, po co i dlaczego się pisze, Londyn 1990.

Bergson H., Materia i pamięć: o stosunku ciata do ducha, tłum. W. Filewicz, Kraków 2012.

Bieńkowski Z., Azyl: poezja i niepoezja, „Tygodnik Kulturalny” 1988, nr 2.

Dąbrowska E., „Mowa petna wahań i zapytañ" - o sztuce poetyckiej Julii Hartwig, "Język Artystyczny” 2003, t. 12.

Deleuze G., Różnica i powtórzenie, tłum. B. Banasiak, K. Matuszewski, Warszawa 1997.

Derrida J., Marginesy filozofii, tłum. A. Dziadek, J. Margański, P. Pieniążek, Warszawa 2002.

80 Taż, Radość [w:] tejże, Gorzkie żale, dz. cyt., s. 8.

${ }^{81}$ Taż, ***(Zatesknitam) [w:] tejże, Spojrzenie, dz. cyt., s. 12.

${ }^{82}$ Taż, Życie, o, życie [w:] tejże, Zapisane, dz. cyt., s. 31 [podkr. - S.B.]. 
Derrida J., Pozycje, tłum. A. Dziadek, Katowice 2007.

Dutka E., Centra, prowincje, zautki. Twórczość Julii Hartwig jako auto/bio/geolgrafia, Kraków 2016.

Eliot T.S., Kto to jest klasyk?, tłum. H. Pręczkowska [w:] tegoż, Kto to jest klasyk i inne eseje, tłum. M. Heydel i in., Kraków 1998.

Ginsberg A., Znajomi z tego świata. Wiersze z lat 1947-1985, ttum. J. Hartwig i in., oprac. P. Sommer, Kraków 1993.

Hartwig J., Btyski, Warszawa 2002.

Hartwig J., Gorzkie żale, Kraków 2011.

Hartwig J., Największe szczęście, największy ból. Jarostawa Mikotajewskiego rozmowy z Julią Hartwig, Kraków 2014.

Hartwig J., Spojrzenie, Kraków 2016.

Hartwig J., Wiersze wybrane, Kraków 2010

Hartwig J., Zapisane, Kraków 2013.

Heidegger M., „...poetycko mieszka cztowiek... ”, tłum. J. Mizera [w:] tegoż, Odczyty i rozprawy, tłum. J. Mizera, Kraków 2002.

Heidegger M., Bycie i czas, tłum. B. Baran, Warszawa 1994.

Heidegger M., W drodze do języka, tłum. J. Mizera, Kraków 2000.

Kaliszewski W., Klasycyzm i Julia Hartwig, „Więź” 1988, nr 6.

Kałuża A., Wola odróżnienia. O modernistycznej poezji Jarostawa Marka Rymkiewicza, Julii Hartwig, Witolda Wirpszy i Krystyny Mitobędzkiej, Kraków 2008.

Kałuża A., Ziemia niczyja. O problemie podmiotu w poezji Julii Hartwig, „FA-art” 2005, nr 4.

Kierkegaard S., Powtórzenie: próba psychologii eksperymentalnej przez Constantina Constantinusa, tłum. B. Świderski, Warszawa 1992.

Kwiatkowski J., Felieton poetycki, „Twórczośc” 1973, nr 9.

Lacan J., Anamorfoza i spojrzenie, tłum. W. Michera [w:] Antropologia kultury wizualnej. Zagadnienia i wybór tekstów, oprac. I Kurz, P. Kwiatkowska, Ł. Zaremba, Warszawa 2012.

Legeżyńska A., Julia Hartwig. Wdzięczność, Łódź 2017.

Łuszczykiewicz P., Być poetą osobnym, „Nowe Książki” 1998, nr 11.

Markowski M. P., Efekt inskrypcji. Jacques Derrida i literatura, Bydgoszcz 1997.

Miłosz C., ${ }^{* * *}$ (W metrze paryskim kartki rozcinatem) [w:] tegoż, Wiersze, t. 2, Kraków 1993.

Nasiłowska A., Poezja jako sposób poznania, „Odra” 1996, nr 5.

Nietzsche F., Radosna wiedza, tłum. M. Łukasiewicz, Gdańsk 2008.

Nikadem-Malinowska E., Powiedzieć więcej - rozważania o synestetyzmie w poezji Josifa Brodskiego i Julii Hartwig, „Acta Polono-Ruthenica” 2003, t. 8.

Nycz R., Poetyka intertekstualna: tradycje i perspektywy [w:] Kulturowa teoria literatury, red. M.P. Markowski, R. Nycz, Kraków 2012.

Pelczar B., W kręgu egzystencjalnych pytań tomiku „Zobaczone” Julii Hartwig, „Zeszyty Naukowe Uniwersytetu Rzeszowskiego. Historia Literatury” 2002, z. 1.

Pessoa F., Ksiega niepokoju spisana przez Bernarda Soaresa, pomocnika ksiegowego w Lizbonie, tłum. M. Lipszyc, Kraków 2013. 
Pochwata istnienia. Studia o twórczości Julii Hartwig, red. B. Kulesza-Gulczyńska, E. Winiecka, Poznań 2015.

Sartre J.-P., Spojrzenie [w:] tegoż, Byt i nicość. Zarys ontologii fenomenologicznej, tłum. J. Kiełbasa, P. Mróz, R. Abramciów, R. Ryziński, Kraków 2007.

Słomczyński S., Dwuptat, Wrocław 2015.

Telicki M., Poetycka antropologia Julii Hartwig, Poznań 2009.

Tomicki G., Poetyckie krązenie wokót „Das Ding”. Funkcje powtórzenia w poezji Eugeniusza Tkaczyszyna-Dyckiego, „Pamiętnik Literacki” 2014, nr 4.

Zaleski M., Mitosz, poeta powtórzenia, „Teksty Drugie” 2001, nr 3-4.

Zaleski M., Nuda powtórzeń? [w:] Nuda w kulturze, red. P. Czapliński, P. Śliwiński, Poznań 1999.

Zaleski M., Zamiast. O twórczości Czestawa Mitosza, Kraków 2005. 